\title{
Impact of Shea Butter Effluent on Biochemical and Heamatological Profiles of Clarias Gariepinus
}

\author{
Adewoye S.O, Adedigba A.E, And Opasola O.A \\ Department Of Pure And Applied Biology Ladoke Akintola University Of Technology, P.M.B 4000 Ogbomoso, \\ Oyo State Nigeria
}

\begin{abstract}
The toxicity of shea Butter effluent (SBE) was investigated with emphasis on hematological, and biochemical profiles of Clarias gariepinus. adults of $280 \mathrm{~g}_{-}{ }^{+} 0.3$. The haematological indices revealed that increased in the concentration of the effluent brings about a corresponding decrease in the PVC, RBC, and Hemoglobin of the test organism. In the other way round, the volume of white Blood cell decreased at concentration of 0.003, 0.005, 0.007, and 0.009 but increased sharply at 0.01 lppt concentration.In the same vein, the shea butter effluents causes a decline in the biochemical composition of Clariasgariepnusvis-à-vis Albumin, protein, cholesterol, Glucose and Urea when compared to the control treatment. Therefore, Shea butter effluent is highly toxic to freshwater fishes, its discharged directly into water bodies, new fish farms or in areas close to aquatic environment should not be encouraged.
\end{abstract}

Keyword: Shea butter, Effluent, Clarias gariepinus, heamatological, biochemical

\section{Introduction}

Fish constitutes a very important component of diet for many people and often provides much needed nutrients not provided elsewhere in animal based diets. Fish is the oldest group of vertebrate and the most numerous with estimates of about 20,000 species. They are of immense importance as a protein source, item of commerce, employment and recreation for humans, as well as, the production of animal feed (FAO, 2000, Adewoye et al., 2005).

About one billion people worldwide rely on fish as their main source of protein as it contains sufficient amounts of all essential amino acids required by the body for growth and maintenance of lean muscle tissue (FRDC, 2001). Over 25,000 metric tones of fish are caught regularly but greater percentages are used for direct human consumption (FAO, 2000).

Fisheries play a major role in the agricultural sector of Nigerian economy, as it is a venture aimed at meeting animal protein of man and to have foreign exchange. Fishes are grown for commercial purpose to meet the dire need of animal protein of man and to earn foreign exchange (Fagadeet al., 1993). Ayeni (1993) reported that Nigeria with about 13 million hectares of freshwater bodies has the potentials of developing fish production as high as $511,702 \mathrm{mt}$ per year, this he observed was because the natural population of fish is being threatened as a result of over exploitation and pollution of various kinds. Hence the potentials for developing fish aquaculture in order to feed the populace and to earn foreign exchange for Nigeria is still very low (Fagadeet al., 1993). Pollution of the aquatic environment with various chemicals is related to nutritional, reproductive, and behavioral problems that have been occurring in organisms, especially fish, living within the polluted are. Consequence, this pollution can create significant problems at either the individual or the population level, and lead to a decrease in the population, resulting in unexpected threats to wildlife and to the human consumers of these organisms. By this decade, biomarker studies, used in the evaluation of environmental health as an indicator of toxic effects of environmental pollutants, have become very important and essential. Changes in biochemical level are the "early warning" responses of an organism to environmental alterations and are critically important. Identification of molecular biomarkers associated with the early prediction, diagnosis and monitoring of major physiological alterations and diseases of fish caused by pollution, may contribute towards in situ conservation of fish populations. As a consequence, biomarkers can be taken as short-term indications of biological effects that will be seen in either the long or short term (Balochet al., 2001). This study was carried out to investigate the effects of shea butter effluent on heamatological and biochemical profiles of C. gariepinus.

\section{Methodology}

This experiment was carried out at the fish laboratory of the Department of Pure and Applied Biology of LadokeAkintola University of Technology, Ogbomoso. 


\section{Collection of Effluents}

The effluents used for the toxicity test were collected from the local factory of shea butter in Te De, the headquarters of ATISBO Local Government in Oke-Ogun area of Oyo state (Plate1) on every three days. This site was chosen based on the fact that these effluents flow into a popular Dam used by two indigenous communities with a population of about one hundred and twenty thousand for domestic purposes.

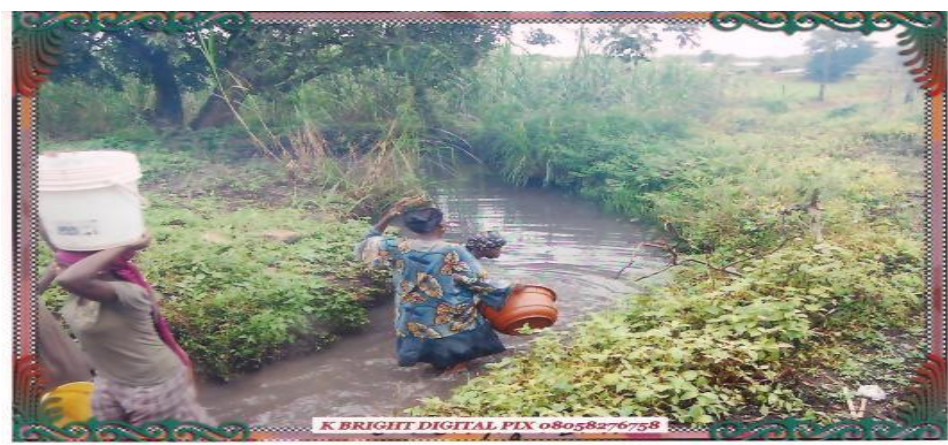

PLATE 1: Showing some Women fetching the polluted water around the factory for domestic use.

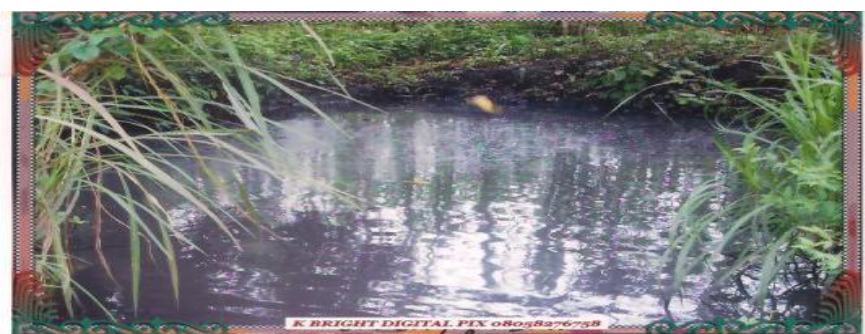

PLATE 2: Showing the impact of the shea butter effluent on the surrounding water body.

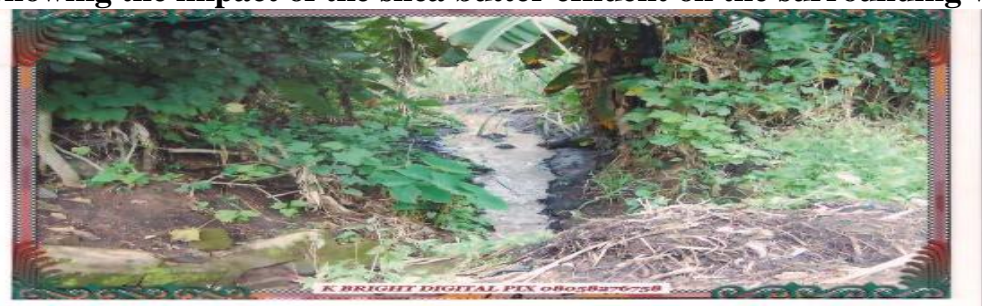

PLATE 3: Movement of shea butter effluent through a sugar cane farm plot

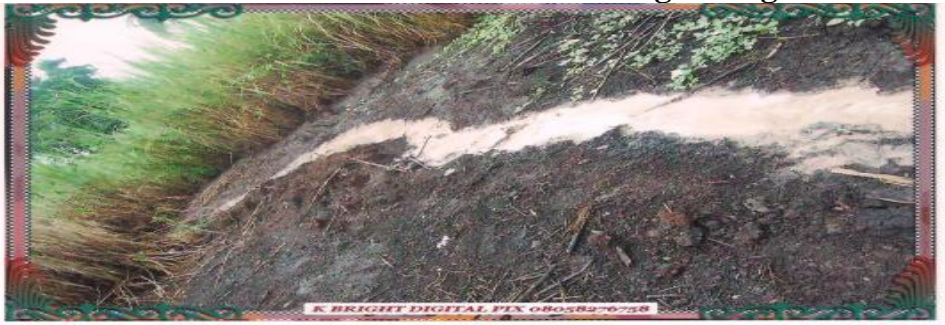

PLATE 4: Showing the effects of shea butter effluent on the surrounding plants

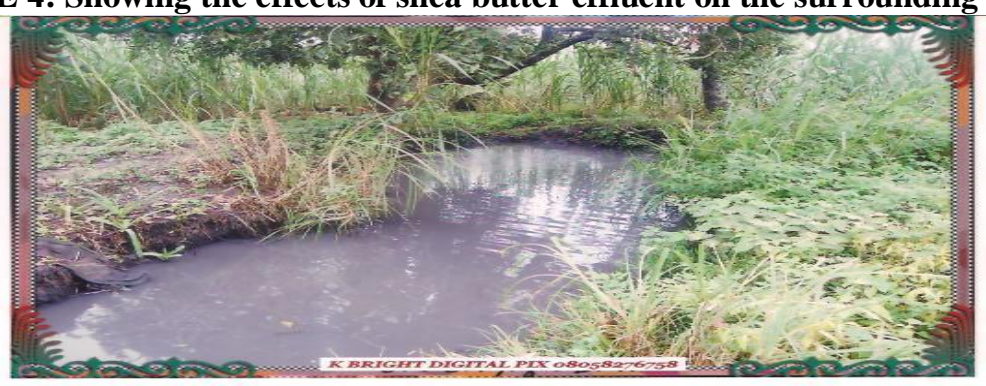

PLATE 5: Polluted water body beside the local factory 


\section{Source, Collection And Maintenance Of Test Organism}

Post-juveniles of C.gariepinus used in this study were procured from Oyo State Ministry of Agriculture, Fishery Division, Ogbomoso. They were transported in a ventilated and aerated plastic container covered with mesh net to prevent being jumped out. The test organisms were transported to the fish laboratory of Department of Pure and Applied Biology of LadokeAkintola University of Technology, Ogbomoso, Oyo State.

\section{Acclimatization of Fish}

The test organisms were held in $30 \mathrm{~cm} \times 30 \mathrm{~cm} \times 60 \mathrm{~cm}$ plastic container containing non-chlorinated borehole water. The borehole water was dechlorinated prior exposure to fresh air for at least three days before usage. The organisms were fed once a day during acclimatization with pelleted vital fish feed to avoid the inherited problem that could result from starvation. This lasted for fourteen days (14 days). Feeding discontinued twenty four hours prior to the commencement of the experiments.

Five concentrations were used based in the result obtained in range finding test. The concentrations used were prepared arithmetically viz; 0.05, 0.06, 0.07, 0.08 and 0.09 . Twenty four hour starved fish were exposed to each of the concentrations of for $96 \mathrm{hrs}$.

The behaviour and general conditions of the fish were observed before, during and after the experiment. The fish were examined of mortality and considered dead when there was no response or gentle prodding. Number of dead fish were recorded and removed immediately from test medium to avoid fouling. The $96-\mathrm{hrsLC}_{50}$ was determined graphically using origin eight statistical package. The fish were kept in the refrigerator prior to heavy metal analysis.

\section{Sub lethal Tests}

Fish utilized for the sub lethal tests were subjected to similar experimental conditions but fed once daily in weighing $5 \%$ of their body weight and monitored for 2 weeks.). after the expiration of the experiment the blood was collected by cardiac puncturing and used for heamatological and biochemical analysis. .

\section{Haematological Analysis}

This was carried out at the Laboratory unit of the University Health Centre, LAUTECH, Ogbomoso according to routine clinical methods.

\section{Packed cell volume (microhaematocrit)}

Immediately after blood collection, one capillary tube of blood from each fish was centrifuge in a microhaematocrit (MK.S centrifuge) produced by Hawkesley and Sons Ltd, England. The centrifugation was done at 1200 RPM for 5 minutes at room temperature. After centrifugation the HCT were determined from the tube directly. The values obtained was recorded as percentage (\%)

\section{Haemoglobin concentration}

About $0.02 \mathrm{ml}$ of the total volume of blood collected was pipette and placed into $4 \mathrm{ml}$ of Drab kin's reagent (potassium fernicyanide, $20 \mathrm{mg}$; potassium cyanide, $50 \mathrm{mg}$ and 1 litre of distilled water). The solution were mixed up gently by inversion and allowed to stand for 10 minutes. Then the mixture was read on photometer at a wavelength of 540nm against working reagent as the blank and this reading were converted to haemoglobin concentration in grams per $100 \mathrm{ml}$, by reference to a graph constructed using commercially available cyanomethaemoglobin standard (Larsson et al., 1948).

\section{Red blood cell and white blood counts}

Blood was drawn directly into the RBC and WBC pipette and diluted with dacie's fluid (99 mc of 33\% aqueous solution of sodium citrate and $1 \mathrm{ml}$ of $40 \%$ formalin). (Decie and Lewis, 1968; Allen, 1973). The diluted solution was introduced into a standard haemocytometer (An improved Nebular counting chamber) and counted in five squares as described by Blaxhall and Daisley (1973) and Allen, (1993). Then, each intermediate square was further divided into 16 small squares. The total RBC counted was multiplied by 100,000 which is the multiplying factor for red blood cells.

\section{Biochemical Analysis}

Blood was collected from the heart of the fish through cardiac puncturing with a needle and syringe, spin in a centrifuge at $5000 \mathrm{rpm}$ and biochemical indices like Total protein, Albumin and Glucose level, sodium, chloride, bicarbonate and calcium contents were analysed. 
Total protein

Total protein $=$ Absorbance of test $\times$ concentration of standard $(4.5 \mathrm{~g})$

Absorbance of standard

Albumin

Glucose

Albumin $=\frac{\text { Absorbance of test }}{\text { Absorbance of standard }} \times$ concentration of standard

Glucose $=\underline{\text { Absorbance of test }} \times$ concentration of standard

Absorbance of standard

\section{Results And Discussion}

Tables 1, 2 and figure 1 show the mean values of the biochemical and hematological indices recorded from exposing of $C$. gariepinus to sublethal concentrations of Shea Butter effluents for 2 weeks. Differences were measured against the control values determined under controlled laboratory conditions.

Table 1:Effects of shea butter effluent on heamatological parameters

\begin{tabular}{lllll}
\hline Concentration $(\mathrm{ppt})$ & $\mathrm{PCV}(\%)$ & $\mathrm{RBC}\left(\times 10^{6} \mathrm{~mm}^{3}\right)$ & $\mathrm{WBC}\left(\times 10^{3} \mathrm{~mm}^{3}\right)$ & $\mathrm{Hb}(\mathrm{g} / \mathrm{dl})$ \\
\hline 0.00 & $47.5 \pm 0.7^{\mathrm{a}}$ & $3.8 \pm 0.0^{\mathrm{a}}$ & $207 \pm 1.4^{\mathrm{a}}$ & $14.45 \pm 0.07^{\mathrm{a}}$ \\
0.003 & $\mathbf{4 7 . 5} \pm 0.7^{\mathrm{a}}$ & $\mathbf{2 . 2 1} \pm 0.07^{\mathrm{b}}$ & $\mathbf{1 1 8 . 5} \pm 0.7^{\mathrm{b}}$ & $\mathbf{1 3 . 5} \pm 0.00^{\mathrm{a}}$ \\
0.005 & $42.5 \pm 0.7^{\mathrm{b}}$ & $\mathbf{2 . 2 1} \pm 0.01^{\mathrm{b}}$ & $\mathbf{1 1 8 . 5} \pm 0.7^{\mathrm{b}}$ & $\mathbf{1 3 . 5} \pm 0.00^{\mathrm{a}}$ \\
0.007 & $\mathbf{4 0 . 5}^{\mathrm{b}} 0.7^{\mathrm{b}}$ & $\mathbf{1 . 9 9} \pm 0.07^{\mathrm{ab}}$ & $\mathbf{1 2 8} \pm 0.0^{\mathrm{c}}$ & $\mathbf{1 3} \pm 0.00^{\mathrm{a}}$ \\
0.009 & $\mathbf{3 3 . 5} \pm 07^{\mathrm{ab}}$ & $\mathbf{1 . 8 2} \pm 0.03^{\mathrm{c}}$ & $\mathbf{1 6 3} \pm 0.14^{\mathrm{ab}}$ & $\mathbf{1 0} \pm 0.00^{\mathrm{b}}$ \\
0.011 & $\mathbf{3 2 . 5} \pm 0.7^{\mathrm{ab}}$ & $\mathbf{1 . 3 2} \pm 0.03^{\mathrm{d}}$ & $\mathbf{2 2 6} \pm 0.7^{\mathrm{d}}$ & $\mathbf{9 . 5} \pm 0.07^{\mathrm{b}}$ \\
\hline
\end{tabular}

Table 2:Effects of shea butter effluent on biochemical indices

\begin{tabular}{|c|c|c|c|c|c|}
\hline Concentration(ppt) & Albumin & Protein & Cholesterol & Glucose & Urea \\
\hline 0.00 & $2.3 \pm 0.00^{\mathrm{a}}$ & $4.2 \pm 0.00^{\mathrm{a}}$ & $130.5 \pm 0.7^{\mathrm{a}}$ & $80.5 \pm 0.7^{\mathrm{a}}$ & $11 \pm 0.00^{\mathrm{a}}$ \\
\hline 0.003 & $2.3 \pm 0.00^{\mathrm{a}}$ & $4.2 \pm 0.00^{\mathrm{a}}$ & $130.5 \pm 0.7^{\mathrm{a}}$ & $\mathbf{8 0 . 5} \pm 0.7^{b}$ & $11 \pm 0.00^{\mathrm{a}}$ \\
\hline 0.005 & $2.3 \pm 0.00^{\mathrm{a}}$ & $4.05 \pm 0.07^{\mathrm{a}}$ & $130 \pm 0.0^{\mathrm{a}}$ & $\mathbf{7 7 . 5} \pm 0.7^{b}$ & $11.5 \pm 0.07^{\mathrm{a}}$ \\
\hline 0.007 & $\mathbf{2 . 3 5} \pm 0.07^{\mathrm{a}}$ & $3.85 \pm 0.07^{b}$ & $128.5 \pm 0.7^{\mathrm{a}}$ & $73 \pm 0.0^{\mathrm{b}}$ & $10 \pm 0.00^{\mathrm{a}}$ \\
\hline 0.009 & $\mathbf{2 . 0 5} \pm 0.07^{b}$ & $3.2 \pm 0.00^{b}$ & $125 \pm 0.0^{\mathrm{b}}$ & $65.5 \pm 0.7^{b}$ & $10.5 \pm 0.07^{\mathrm{a}}$ \\
\hline 0.011 & $\mathbf{1 . 8 5} \pm 0.07^{\mathrm{ab}}$ & $\mathbf{2 . 8 5} \pm 0.07^{\mathrm{ab}}$ & $119.5 \pm 0.7^{a b}$ & $\mathbf{5 6 . 5} \pm 0.7^{\mathrm{ab}}$ & $9 \pm 0.00^{b}$ \\
\hline
\end{tabular}

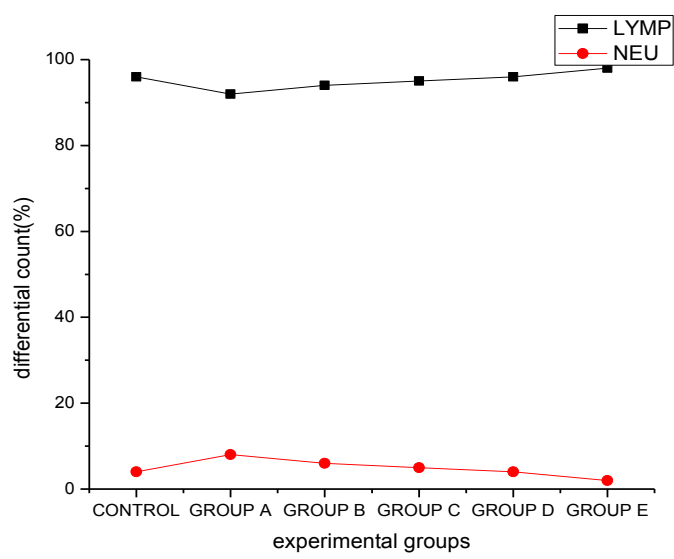

Fig.1: Differential count of the blood parameters

\section{Discussion}

Hematological studies have proven note wothy for fisheries biologists in assessing the health of fish.

Evidently, blood is the most important body fluid and its composition usually reflects the physiological condition of the body, so it provides an ideal tool for toxicological stress studies (Lee, 1996). Blood parameters in fish have been studied to elucidate physiological adaptation and to assess the health status of fishes (Canfield et al., 1994). Possibility of using heamatocrit(PCV) and Haemoglobin ( $\mathrm{Hb})$ as tools for checking anaemic condition in fishery management and aquaculture has been extensively studied.

The use of White blood cells (WBC) has also been reported to be a useful indicator of diseased condition or extent of infection as elevated values are obtained in abnormal condition (Etimet al., 1999).Haematological parameters such as erythrocyte count, haemoglobin concentration, haematocrit value vary in fish in response to different toxicants. The striking alterations in the blood parameters and associated 
pathological changes in fishes under the influence of various toxic agents have been reported byKumar etal., (1999) and Nair (2000) amongst others .

For instance, Omoregieet al. (1990) documented a significant decline in red blood cell count and haematocrit levels of $O$. niloticusexposed to sublethal concentrations of gammalin 20 and Actellic 25 EX, there was however an increase in the count of glucose with increase in exposure time. Vanvurenetal., (1994) documented a significant decrease in RBC, PCV, WBC and Glucose levels of $C$. gariepinus exposed to copper.

The decrease in haematological profiles of $C$. gariepinus exposed to shea butter effluent is an indication of diseased condition. Especially, the decrease in the quantity and quality of erythrocytes i.e PCV and heamoglobin concentration is an indication of anaemia. Also, the decline in the Red Blood Cell value reflect the health deteriorating condition of the fish.

Similarly, the striking alterations in the blood parameters and associated pathological changes in fishes under the influence of various toxic agents have been reported by Kumar et al., (1999) and Nair (2000).

\section{Conclusion And Recommendation}

Investigations into the effects of Shea butter effluent revealed that it is toxic to aquatic organisms and causes reduction in the haematological and biochemical indices of $C$. gariepinus. It is therefore obvious in this study that shea butter effluent is highly toxic to the test organism as revealed by its impact on the heamatological and biochemical indices of the test organism. Indiscriminate discharge of this effluent should be seriously campaign against.

\section{References}

[1]. Adewoye S.O., O.O., Owolabi, O.D and Omotosho J.S. (2005): Toxicity of Cassava wastewater effluent to African catfish: Clariasgariepnus. Ethiop.J.Sci, 28(2) pp. 189-194

[2]. APHA (1989): Standard methods for examination of water and wastewater (17 ${ }^{\text {th }}$ Edition): prepared and published jointly by: American Public Health Association (APHA); American Water Works Association (AWWA) and Water Pollution Control Federation (WPCF), New York.

[3]. Ayeni, J.S.O (1993): The Challenge of conservation and development of Nigerian quatic resources.Proceedings of the national conferences cadmium To jureniles of Clariasgariepnus(Teugels) and Orechromisniloticus (Trewavas).Journal of Environmental Science and Health.29(7); 1357.

[4]. Canfield, P.J., Quartararo, N., Griffen, D.L., Tsoukalas and Cocaro, S.E. (1994): Haematological and biochemical reference values for captive Australian snapper, Pagrusauratus. Journal of fish Biology 44: 849 - 856

[5]. Etin,L., Ekanem, S.B and Utin, A (1999): Hematological profile of two species Of catfish, Chrysichthysnigrodigitatus(Lacepede) and Chrysichthys Fureatus(Gunter) from the Great Kwa River, Nigeria. Global J. Pure And Applied Sci. 5(1):1- 4.

[6]. Fagade. S.O., Adebisi, A.A and Ugwumbu, O.A (1993): Conservation of aquatic resources through aquaculture. Proceeding of the national conference on Conservation and aquatic resources.Organized by National Advisory Committee on Conservation of Renewable Resources. In cooperation With Federal Department of Fisheries, Abuja and Nigerian Institute For oceanography and Marine Researches, Lagos. Pp 176 - 192.

[7]. FAO (2000): Fisheries resources: Trends in production, utilization and trade. 43p.

[8]. FRDC (2001): What is so healthy about seafood? A guide for sea food marketers. Fishers Research and Development Corporation.Australia.36p-

[9]. Kumar, K. Sinha, Y.K.P and Pandey, A.K (1999): Mecuric Chloride induced lterations in the blood parameters of the climbing perch. Anabas testudines (bloch). J. Nature Conserv. 11(2): 245-255.

[10]. Lee, E.L., (1996): Measurement of pesticides toxicity by fish respiration rate D. Sc. Thesis. Washington University=

[11]. Nair, S. 2000 - Toxic effect of mercury on the haematological parameters of Oreochromismossambicus (peters). Poll. Res. 19(3): $399-402 \mathrm{pp}$

[12]. Omoregie, E, Ufodike, E.B.C and Keke, I.R. (1990): Tissues chemistry of O. niloticusexposed to sublethal concentrations of Gammalin 20 and Actellic 25EC. J. of Aquatic Science, 5: $33-36 \mathrm{pp}$.

[13]. VanVuren J.H.J. Van der Merwen, M and Dupreez H.H (1994): The effect of copper on the blood chemistry of Clarias gariepinus (Clariidas). Ecotoxicol. Environ. Saf 29187 - 199pp. 